\title{
SUSTAINABILITY STUDY OF DEWATS SYSTEMS AT PERI URBAN AREAS IN BANGALORE
}

\author{
Shivendra. B. T ${ }^{1}$, Ramaraju. H. K \\ ${ }^{I}$ Dayananda Sagar College of Engineering Department of Civil Engineering, Bangalore-560078, India \\ Email: shivubts@yahoo,com \\ ${ }^{2}$ Dayananda Sagar College of Engineering Department of Civil Engineering, Bangalore-560078, India
}

\begin{abstract}
Threats to groundwater quality from on-site sanitation can be mitigated through technology design. Innovative Technologies like Dewats systems, Ecosan, E-toilets, Bio-toilets are implemented by Government and various NGO in peri urban areas and slum areas of urban areas. Most of the sanitation programmers have failed due to lack of appropriate social mechanism. In the present study two sites with Dewats onsite system in the Peri urban area in Bangalore are selected to compare sustainability, affordable and culturally acceptability to poor populations in low-income countries. The study found that at both places systems are working satisfactorily for treatment of Domestic waste water. The local community people had socially accepted Dewats system.
\end{abstract}

Keywords: Onsite Sanitation. Dewats, Peri Urban Area, Sustainability

\section{INTRODUCTION}

To achieve Millennium Development Goals target, one billion people in urban areas and 900 million people in rural areas must gain access to improved sanitation by 2015 over the baseline year, 1990 (WHO/UNICEF 2012). More than one third of the world's population does not have access to improved sanitation. Of the 2.5 Billion people in the world that defecate openly, 665 million live in India. This is of greater concern as $88 \%$ of deaths from diarrhoea occur because of unsafe water, inadequate sanitation and poor hygiene. The Indian sanitation system is inadequate amenities and poor hygiene. The existing conventional sanitation facilities in cities and towns lack proper hygiene and cleanliness. The people hesitate to make use of the public provision for sanitation. Due to lack of appropriate maintenance, insufficient manpower to maintain the units and improper treatment of waste disposal, there is a need to provide an aesthetic, clean, hygienic sanitation. Most Indians depend on on-site sanitation facilities, mostly unimproved pit latrines, and septic tanks.

The majority of people living in the rural areas and on the urban fringes in developing countries still lack satisfactory sanitation. on-site sanitation is still the most widespread mode of sanitation available. poor design of on-site sanitation systems, dense habitation and a combination of physical hydro geologic factors result in threat to the contamination to fresh groundwater resources. Drinking water in both rural and urban parts of the developing world being highly decentralized and dependant critically on aquifers, contamination of groundwater via on-site sanitation has a heavy public health burden, visible through a host of diseases, causing widespread morbidity and mortality.
The sanitation technologies should shift communities away from open defecation and promoting safe sanitation, health and hygiene facilities. The Government and other agencies are finding it difficult select the technology which suits to both culturally, technically and economically. The present challenge to India is to develop safe and affordable sanitation that effectively removes human waste from the environment with recovery of nutrients and recycling of treated wastewater.

Threats to groundwater quality from on-site sanitation can be mitigated through technology design, risk assessment, development of protection zones, and monitoring (Lawrence et al. 2001; Lewis et al. 1982). Latrine liners can minimize seepage of pit contents to groundwater Urine diverting toilets, Composting toilets and ecological sanitation technologies may reduce microbial risks and minimize chemical leaching from pit latrines. However, it remains unclear whether these alternative systems are affordable and culturally acceptable to poor populations in low-income countries (Mariwah and Drangert 2011).

Innovative Technologies like Dewats systems, Ecosan, Etoilets, Bio-toilets are implemented by Government and various NGO in peri urban areas and slum areas of urban areas,based on availability hydro geological features, topography, soil conditions meteorological aspects and on people mind set. The present study is to investigate effectiveness of Dewats for peri-urban areas, near Bangalore peri urban areas, and the impact of treatment on the Environment.

Objectives: In the present study the feasibility of Dewats system at two places in peri-urban areas of Bangalore is investigated with the following objectives. To compare the suitability and sustainability of Dewats in peri-urban areas 
and their affordability and culturally acceptability to poor populations in low-income countries.

Dewats; Dewats are defined as "onsite or cluster wastewater system used to treat and dispose of small volumes of wastewater from individuals, dwellings or businesses that are located relatively close to each other." Dewats are small, individual or cluster type wastewater facility for housing colonies, hospitals and for apartments. It provides primary, secondary and tertiary treatment with efficient reuse of water, energy and manure as fertilizer. Dewats is appears to be well suited for local ecological condition, affordable and adaptable with a fraction of the cost of conventional, centralized sewerage system It is recognized as an alternative for areas that are not having centralized sewerage systems. The Dewats treats wastewater on site using low cost systems, and reuse of the treated effluent, sludge and biogas for other productive uses (Anh et.al. 2003). Dewats can offer treatment to domestic and industrial wastes with a narrow COD/BOD ratio, and daily flows between 1 to $1,000 \mathrm{~m}^{3}$. (Gutterer et al. 2010). The Dewats is capable of serving 200 to1,500 people with a demand of 200 litre per capita per day. (Van-Haandel et al. 2006 ). Dewats can be applied in medium and small cities with or without sewer systems and smaller communities in the urban fringes in developing countries (GTZ 2001, Anh et al. 2003.) The Dewats is suitable for developing countries with tropical and subtropical climate Where the temperatures is between $18^{\circ} \mathrm{C}$ and $35^{\circ} \mathrm{C}$.(suitable for anaerobic digestion and bacterial growth.).Dewats Uses both Aerobic and anaerobic techniques. Aerobic modules comprises of planted gravel filters and polishing ponds. Anaerobic modules comprise of settlers, baffle reactors and anaerobic filters. Primary treatment which includes pre-treatment and sedimentation in settlers or septic tank. Secondary anaerobic treatment includes Baffled reactors or fixed bed filters. Tertiary aerobic/anaerobic treatment includes planted gravel filters. Aerobic treatment includes polishing ponds.

The concept Dewats should focus on the treatment and reuse of resources like bio-energy, plant nutrients (Nitrogen and Phosphorous) produced during treatment, and recycling effluent water. use of Dewats in developing countries with tropical and subtropical climate may have a promising future in addressing urban sanitation (Anh Viet et al., 2003). Depending on the degree of treatment required, Dewats for domestic wastewater treatment usually consist of high rate anaerobic reactors such as bio-digester, bio-settler, Anaerobic Baffled Reactor, Anaerobic Filter and Planted Gravel Filter (constructed wetland.).

\section{Study area}

Treatment Unit at site No.1.(Fig.1) Community Based Sanitation is situated in peri-urban Bangalore is a group housing project of the government for the economically weaker section of people around 600 engaged in Beedi making (cottage industrial work). The housing project is funded under the Vambay scheme. The area is 2 acres. The waste water is collected from Toilets, bathrooms, laundry and urinals of beedi workers colony and is treated in Dewats system. The plant Design capacity: $36 \mathrm{~m} 3 / \mathrm{d}$. .The treatment unit consists of two numbers Biogas settler, volume $28.55 \mathrm{~m} 3$, extension chamber Volume: $5.7 \mathrm{~m} 3$, , 48 No. of chambers baffle reactor, with Volume: $109 \mathrm{~m} 3$ and Planted gravel filter consists of Gravel , Reed juncas,Colacasia Plants. The wastewater from Toilets, bathrooms, laundry and urinals is collected from all houses in a common chamber and from it enters into biogas settler. In biogas settler anaerobic digestion takes place, Biogas produced enters into the extension chamber where it is stored for heating water. From the biogas settler, wastewater enters into numbers of baffled reactors where again anaerobic digestion takes place. The treated wastewater then enters to the horizontal planted gravel filter where waste water is treated aerobically and fine colloidal suspended organic matters and nutrients are adsorbed and Pathogen are removed.Treated wastewater for gardening.

Treatment Unit at site No2. (Fig.1) A Trust supporting Mentally challeged persons is situated in peri-urban Bangalore is a organisation, mainly work with adults with Mental retardation, around 40 to70 in numbers. The waste water is collected from Toilets, bathrooms, and urinals is treated in Dewats system. The plant Design capacity: 9m3/d. The treatment unit consists of Biogas settler volume $7 \mathrm{~m} 3$, extension chamber Volume: 2m3, , 16 No. of chambers baffle reactor, with Volume: $35 \mathrm{~m} 3$, Planted gravel filter consists of Grave 129m3 , Reed juncas, Colacasia Plants. and Collection pond of volume $15 \mathrm{~m} 3$. The wastewater from Toilets, bathrooms, and urinals is collected from the house in a common chamber and from it enters into biogas settler. In biogas settler, anaerobic digestion takes place, Biogas produced enters into the extension chamber where it is stored for cooking purpose.. From the biogas settler, wastewater enters into numbers of baffled reactors where again anaerobic digestion takes place. The treated wastewater then enters to the horizontal planted gravel filter where waste water is treated aerobically and fine colloidal suspended organic matters and nutrients are adsorbed and Pathogen are removed. Treated wastewater finally enters into the polishing pond where the water is stored for gardening and for horticulture requirement. 


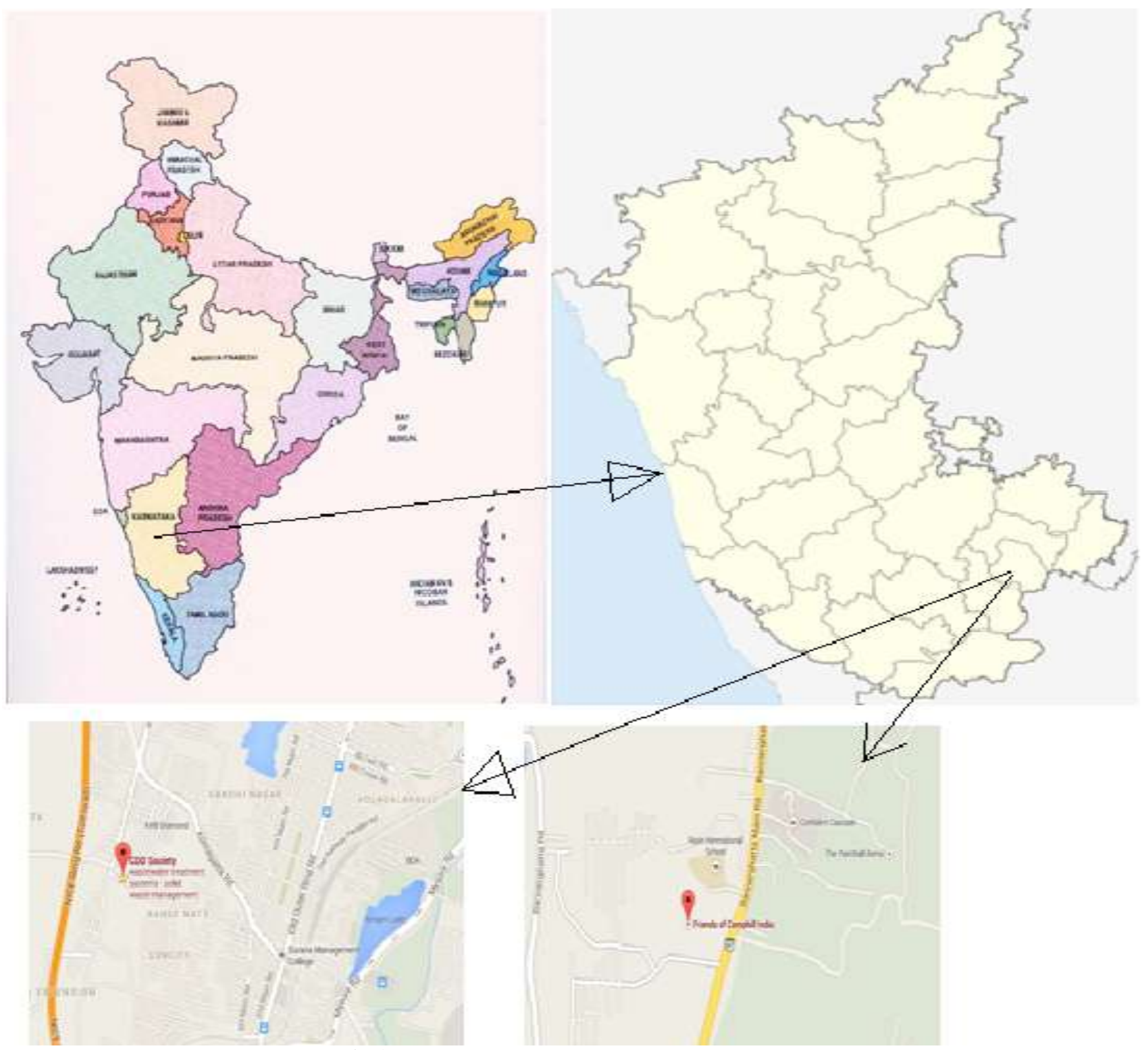

Fig 1. Map showing location of study areas 1 and 2

\section{Methodology}

Samples are collected twice at inlet and outlet from various treatment units of two Dewats plants situated at site nol and site no2 at regular time interval of 15 days for three months. Water samples are collected as per standard methods (APHA) in 2Litre plastic cans for physico-chemical analysis and $300 \mathrm{ml}$ water sample in sterilized bottle for bacteriological study. The collected samples are preserved in the lab and tested for various physico-chemical and biological parameters within a week as per standard methods (APHA)

\section{Results and Discussion;}

The performance of Dewats in terms of treatment was assessed through the removal efficiencies of major physical, chemical and microbiological contaminants. The results of analysis of influent and effluent from various modules of Dewats at Site No1 and 2 are tabulated in Table 1 and 2. The key parameters used to assess treatment efficiencies were: PH, Turbidity, Suspended Solids (SS), Chloride, Ammonia Sodium, Potassium, Chemical Oxygen Demand (COD), Bio-Chemical Oxygen Demand (COD), Nitrate (NO3), Escherichia Coli (E-coli), and Colony Forming Unit (CFU).The tables compare effluent values against Central Pollution Control Board(CPCB).The average effluent values were within the required effluent quality as stipulated by the Central Pollution Control Board(CPCB) statutory requirement for effluent disposal. 
Table1: Average values influent and effluent wastewater parameters of study area: 1

\begin{tabular}{|c|c|c|c|c|c|}
\hline $\begin{array}{l}\text { Physico-Chemical and } \\
\text { bacteriological Parameters }\end{array}$ & Inlet to plant & Inlet to $\mathrm{ABR}$ & Inlet to PGF & Outlet to drain & $\begin{array}{l}\mathrm{CPCB} \\
\text { limits }\end{array}$ \\
\hline $\mathrm{PH}$ & 7.395 & 7.49 & 7.67 & 7.81 & $6-8$ \\
\hline Turbidity & 115 & 54 & 19 & 6 & 20 \\
\hline Suspended solids(mg/l) & 2680 & 1720 & 600 & 360 & 100 \\
\hline $\mathrm{COD}(\mathrm{mg} / \mathrm{l})$ & 601 & 349 & 145 & 41 & 250 \\
\hline $\mathrm{BOD}(\mathrm{mg} / \mathrm{l})$ & 333 & 190 & 60 & 18 & 30 \\
\hline Chloride(mg/l) & 555 & 510 & 425 & 370 & 600 \\
\hline Nitrate $(\mathrm{mg} / \mathrm{l})$ & Nil & Nil & Nil & 13 & 10 \\
\hline Ammonia & 4 & 4 & 3.25 & 2.75 & 5 \\
\hline Sodium(mg/l) & 38 & 50 & 47 & 49 & 60 \\
\hline Potassium(mg/l) & 14 & 14 & 13 & 12 & --- \\
\hline E-coli & Present & Present & Nil & Nil & Absent \\
\hline $\begin{array}{l}\text { Colony forming unit; } \\
\text { CFU/100 ml }\end{array}$ & 800 & 560 & 335 & 140 & 100 \\
\hline
\end{tabular}

Table 2: Average values influent and effluent wastewater parameters of study area: 2

\begin{tabular}{|l|l|l|l|l|l|l|}
\hline $\begin{array}{l}\text { Physico-Chemical and Inlet to } \\
\text { bacteriological Parameters } \\
\text { plant }\end{array}$ & $\begin{array}{l}\text { Inlet to } \\
\text { ABR }\end{array}$ & Inlet to PGF & $\begin{array}{l}\text { Inlet } \\
\text { polishing } \\
\text { pond }\end{array}$ & to & $\begin{array}{l}\text { Outlet } \\
\text { limit }\end{array}$ \\
\hline PH & 7.23 & 7.25 & 7.17 & 7.43 & 7.75 & $6-8$ \\
\hline Turbidity(mg/l) & 73 & 51 & 44 & 12 & 5 & 20 \\
\hline Suspended solids(mg/l) & 6960 & 2060 & 780 & 540 & 430 & 100 \\
\hline COD(mg/l) & 315 & 215 & 180 & 120 & 55 & 250 \\
\hline BOD(mg/l) & 145 & 133 & 120 & 65 & 25 & 30 \\
\hline Chloride(mg/l) & 317 & 267 & 261 & 265 & 250 & 600 \\
\hline Nitrate(mg/l) & 50 & Nil & Nil & 8 & 16 & 10 \\
\hline Ammonia(mg/l) & 8 & 7 & 5 & 8 & 6 & 5 \\
\hline Sodium(mg/l) & 18 & 17 & 16 & 15 & 14 & 60 \\
\hline Potassium(mg/l) & 11 & 11 & 12 & 11 & 11 & ---- \\
\hline E-coli & Present & Present & Nil & Nil & Nil & Absent \\
\hline $\begin{array}{l}\text { Colony forming unit; } \\
\text { CFU/100 ml }\end{array}$ & 825 & 625 & 550 & 150 & 100 & 100 \\
\hline
\end{tabular}

The results of analysis of influent and effluent from various modules of Dewats at Site No1 and 2 are tabulated in Table 1 and 2. According to the obtained test results, graphs are plotted for various parameters like PH, Suspended Solids (SS), Chemical Oxygen Demand (COD), Bio-Chemical Oxygen Demand (COD) and Colony Forming Unit (CFU).

PH; The findings as analysed in the Plant 1 shows that mean $\mathrm{pH}$ of raw wastewater increases as it passes through various units. This might be due to a very efficient hydrolysis step or acidogenesis in the plant. This would reduce the amount acids being produced in the plants and thus leading to a slightly higher $\mathrm{pH}$ than neutral.,as the hydrolysis being the slowest step in anaerobic digestion. Whereas Plant 2 shows a slight decrease of the PH from digester till PGF (This may due amount acids being produced during anaerobic digestion)and a higher value from PGF till outlet signifying continuous degradation and decomposition of organic matter during anaerobic and post treatment. The comparison of PH between Two plants is shown in the Fig1 and 2. In both the effluents, the final effluent was within the 6.0-8.0 $\mathrm{PH}$ allowable limits required for optimum treatment of wastewater.

Suspended Solids(SS); The Fig3 and 4 shows Suspended Solids reduction trends during the treatment process for Plant 1 and 2. In the Plant1, Suspended Solids amounts reduced from $2680 \mathrm{mg} / \mathrm{l}$ in the influent digestor to $360 \mathrm{mg} / \mathrm{l}$ in the final effluent, signifying $87 \%$ treatment efficiency. Where as in the second plant, reduction is from $6960 \mathrm{mg} / \mathrm{l}$ in the digester to $430 \mathrm{mg} / \mathrm{l}$ in the effluent indicating $94 \%$ treatment efficiency. The increase in the percentage efficiency in the latter may be due to the additional polishing pond which enhances settlement of particles.

Chemical Oxygen Demand (COD); The reduction in COD across the different units is shown in the Fig5 and6. The average COD influent for first Plant was $601 \mathrm{mg} / \mathrm{l}$, which reduced to $41 \mathrm{mg} / \mathrm{l}$ in the final effluent after treatment, which signified $93 \%$ treatment efficiency. Similarly average COD 
influent for second plant was $315 \mathrm{mg} / \mathrm{l}$ and its final effluent was $55 \mathrm{mg} / \mathrm{l}$ which indicated $83 \%$ treatment efficiency.

Bio-chemical Oxygen Demand (BOD); According to the Fig7 and 8, BOD dropped from $333 \mathrm{mg} / \mathrm{l}$ in the inlet to $18 \mathrm{~m} / \mathrm{l}$ in the effluent, signifying $95 \%$ efficiency for the first plant and $145 \mathrm{mg} / \mathrm{l}$ in the inlet to $25 \mathrm{mg} / \mathrm{l}$ in the effluent in plant 2 signifying $83 \%$ efficiency.

Bacterial removal; Both the plants show good removal of Colony Forming Unit (CFU). Plant 1 removes CFU with 83\%Efficiency and also Plant 2 also removes CFU with $88 \%$ efficiency. The international standard limit for CFU/100ml removal is 100 which confirm excellent removal. The E-coli is effectively removed in secondary treatment units and final effluents are free from E-coli.

Effectiveness of wastewater treatment ; Treatment unit at site no.1 removes $94 \% \mathrm{BOD}$ and $93 \% \mathrm{COD}$ and satisfies the effluent disposal requirements. The pathogen removal is not satisfactory, as it does not fulfill the requirements of Karnataka pollution control board for disposal of treated effluents. Treatment unit at site no. 2 removes $82 \%$ BOD and $82 \%$ COD and satisfies the effluent disposal requirements. The pathogen removal is satisfactory, as it fulfill the requirements of Karnataka pollution control board for disposal of treated effluents.

Acceptance of the technology and Community participation; The local community people had socially accepted the technology because it affordable. The waste water treatment plant is operated and maintained by the trained members of colony.

\section{CONCLUSION}

In both case studies it is found that removal of, BOD COD, and pathogens by Dewats for domestic treatment is Satisfactory. Dewats technology as an appropriate model for treatment of black water from toilets, and reuse of treated wastewater and usage of methane gas a cooking fuel. Dewats are sustainable in study areas with the local residents participation and active maintenance. The treated effluents meets requirements of Karnataka pollution control board for disposal of treated effluents. . The two case studies are a good examples for showcasing the effective implementation of sanitation solutions in a peri-urban area.

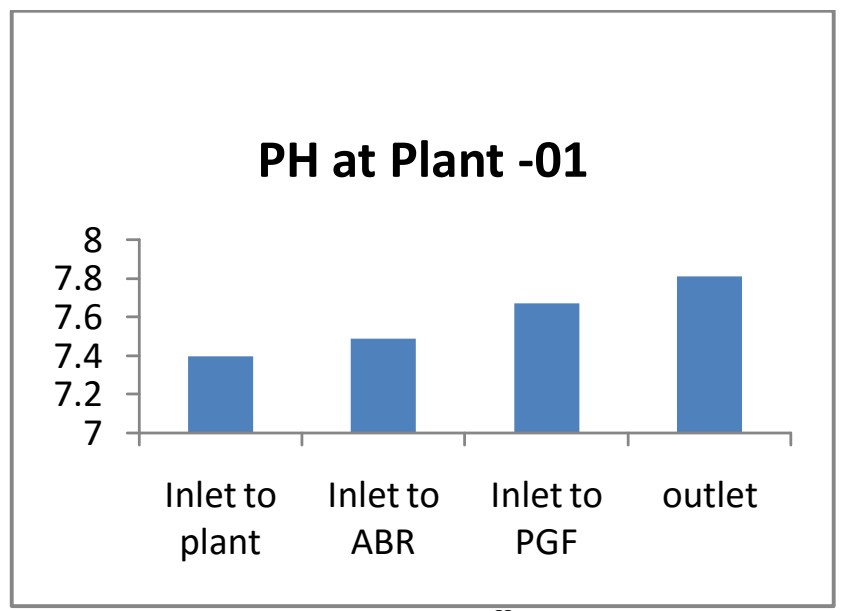

Fig 1. Variation of $\mathrm{P}^{\mathrm{H}}$ at plant1

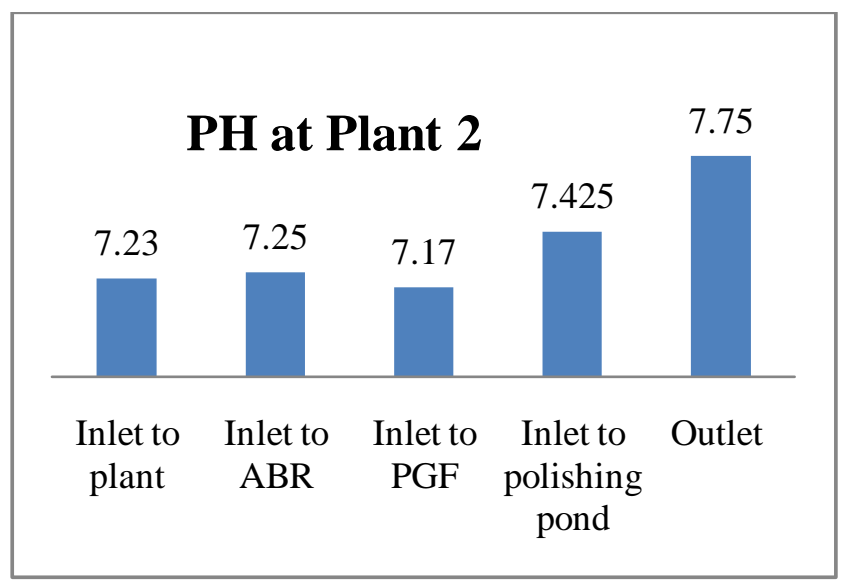

Fig 2. Variation of $\mathrm{P}^{\mathrm{H}}$ at plant2

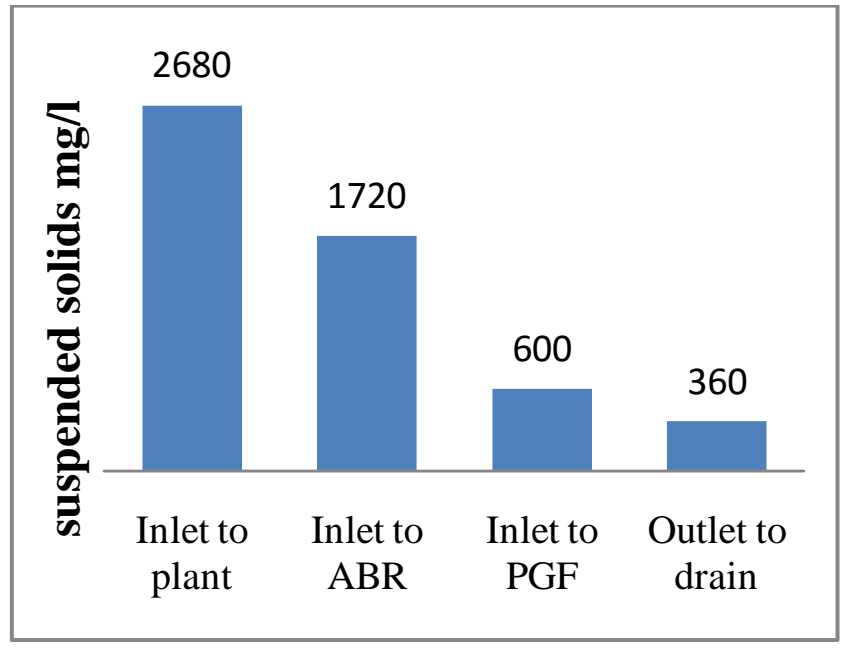

Fig 3. Variation of Suspended Solids at plant1 


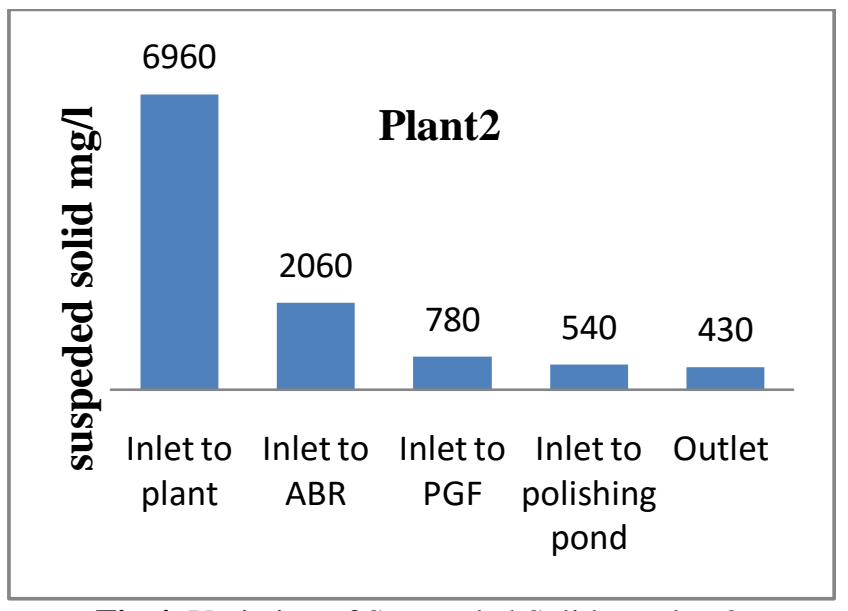

Fig 4. Variation of Suspended Solids at plant2

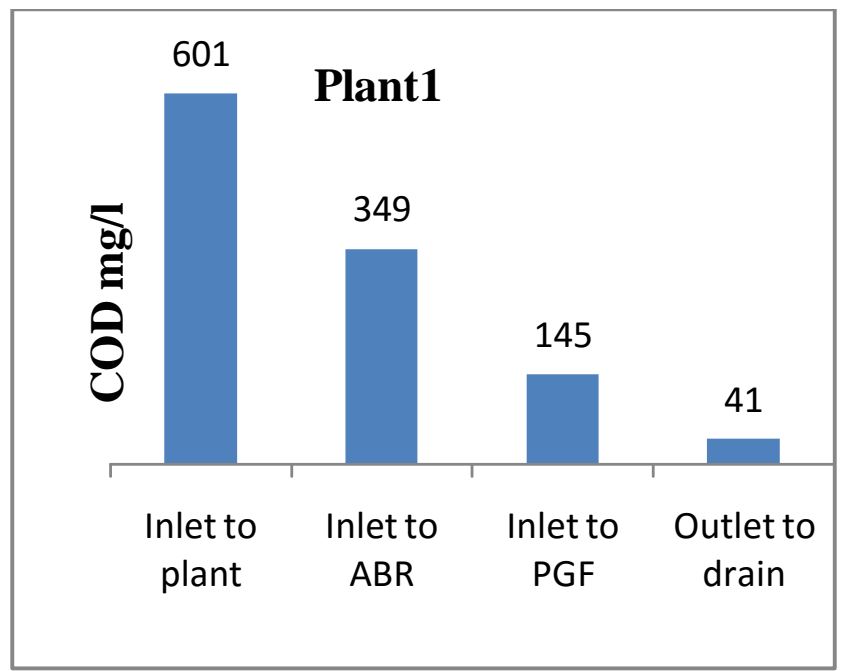

Fig 5. Variations of COD at Plant 1

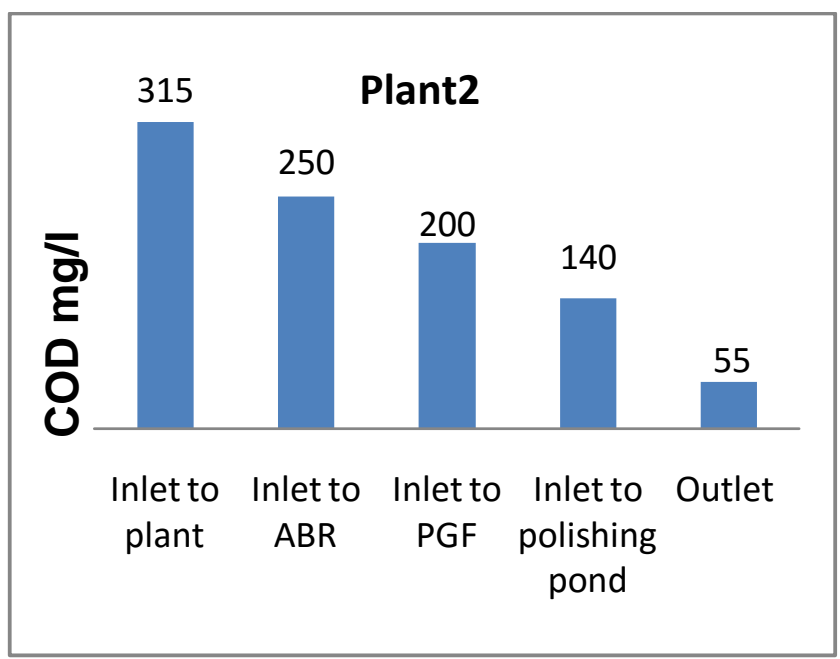

Fig 6. Variations of COD at Plant 2

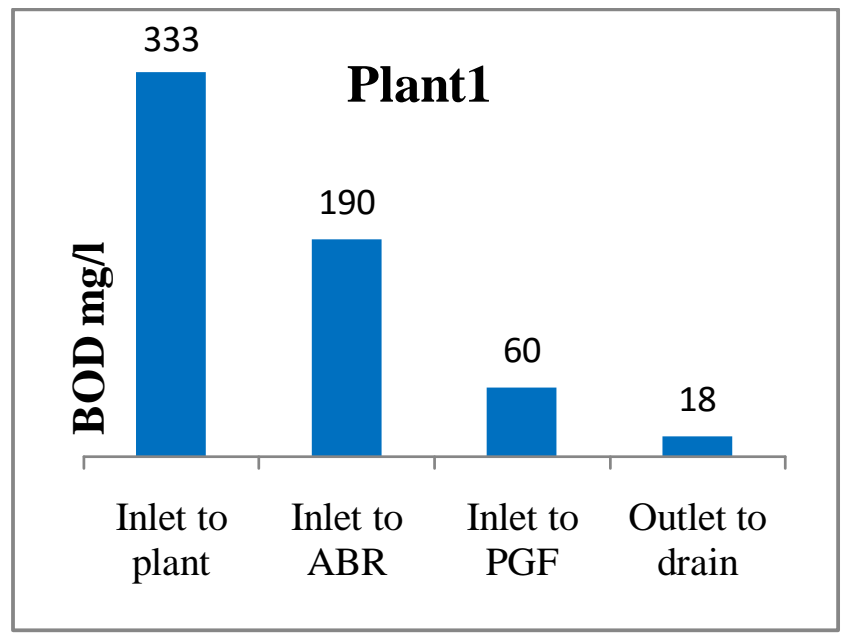

Fig 7. Variations of BOD at plant 1

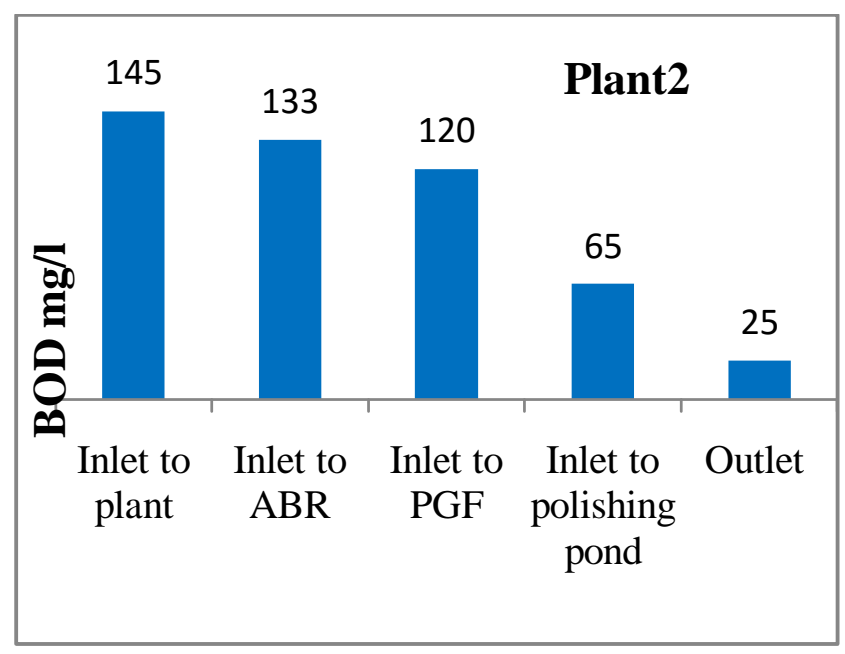

Fig 8. Variations of BOD at plant 2

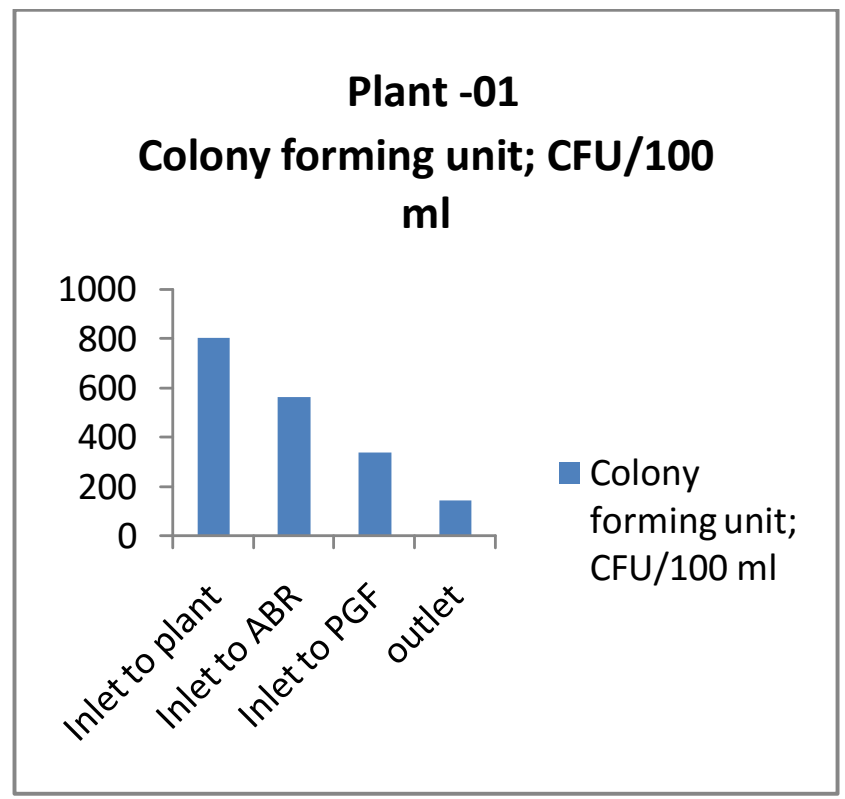

Fig 9. Variations of colony forming units at plant 1 


\section{Plant -02 \\ Colony forming unit; CFU/100 ml}

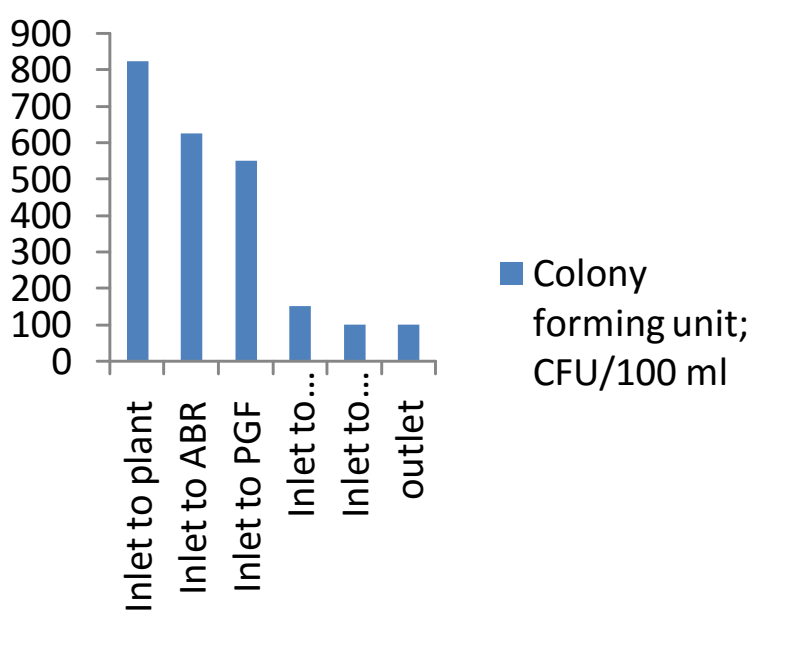

Fig 10. Variations of colony forming units at plant 1

\section{ACKNOWLEDGEMENTS}

Authors express their sincere thanks to Principal and Management of Dayananda Sagar College of Engineering , Bangalore, for providing facilities and their encouragement and BORDA, Bangalore for permission granted to collect wastewater samples from Dewats units.

\section{REFERENCES}

[1] APHA (American Public Health Association), Standard methods for examination of water and wastewater specifications, 19th Edition, Washington.D.C. 2003

[2] ARGOSS,. Guidelines for assessing the risk to groundwater from on-site sanitation. BGS Report CR/01/142, Key worth. 2001

[3] BORDA, "DEWATS-Decentralized Wastewater Treatment Systems-Demand Based Technical Solutions to Reduce Water Pollution by Small and Medium Enterprises and Settlements in Densely Populated Areas." Germany. 2005.

[4] GTZ and Gate Information Service,. "Decentralized Wastewater Treatment Methods for Development Countries", Technical Information W8e Frankfurt.2001

[5] Gutterer, B., L. Sasse, T. Panzerbieter, T. Reckerzudel and T. Recerzugel, "Decentralised Wastewater Treatment System and Sanitation in Developing Countries.", A practical guide, WEDC, London. 2010.

[6] Lawrence, A. R., et al. Guidelines for assessing the risk of groundwater from on-site sanitation.Commissioned report (CR/01/142) of British Geological Survey. 2001

[7] Lewis, W. J., S. S. D. Foster, et al.. The risk of groundwater pollution by on-site sanitation in developing countries: A literature review, International Reference Centre for Wastes Disposal, 1980

[8] Sasse L,. DEWATS-Handbook on the Decentralized Wastewater Treatment in Developing Countries, Bremen.1998 